OPEN ACCESS

Edited by:

Bing-Xing Pan,

Nanchang University, China

Reviewed by: Yan Dong,

University of Pittsburgh, United States

Qingchun Tong,

University of Texas Health Science

Center at Houston, United States

Anton Ilango,

Otto-von-Guericke Universität

Magdeburg, Germany

*Correspondence:

Modi Yang

yangmodi0513@163.com

Shuohui Gao

gaoshuohui@foxmail.com

Jiayin Lv

Ivjiajinmg63@sina.com

Bingjin Li

libingjin@jlu.edu.cn

Specialty section:

This article was submitted to

Neuroendocrine Science,

a section of the journal

Frontiers in Neuroscience

Received: 31 January 2018

Accepted: 25 July 2018

Published: 14 August 2018

Citation:

Jie $F$, Yin G, Yang W, Yang $M$, Gao S,

Lv J and Li B (2018) Stress

in Regulation of GABA Amygdala

System and Relevance

to Neuropsychiatric Diseases.

Front. Neurosci. 12:562.

doi: 10.3389/fnins.2018.00562

\section{Stress in Regulation of GABA Amygdala System and Relevance to Neuropsychiatric Diseases}

\author{
Fan Jie', Guanghao Yin ${ }^{1}$, Wei Yang ${ }^{1}$, Modi Yang ${ }^{2 *}$, Shuohui Gao ${ }^{2 *}$, Jiayin $L^{3 *}$ and \\ Bingjin Li* ${ }^{*}$
}

\begin{abstract}
1 Jilin Provincial Key Laboratory on Molecular and Chemical Genetic, The Second Hospital of Jilin University, Changchun, China, ${ }^{2}$ Department of Gastrointestinal Colorectal Surgery, China-Japan Union Hospital of Jilin University, Changchun,

China, ${ }^{3}$ Department of Orthopedics, China-Japan Union Hospital of Jilin University, Changchun, China
\end{abstract}

The amygdala is an almond-shaped nucleus located deep and medially within the temporal lobe and is thought to play a crucial role in the regulation of emotional processes. GABAergic neurotransmission inhibits the amygdala and prevents us from generating inappropriate emotional and behavioral responses. Stress may cause the reduction of the GABAergic interneuronal network and the development of neuropsychological diseases. In this review, we summarize the recent evidence investigating the possible mechanisms underlying GABAergic control of the amygdala and its interaction with acute and chronic stress. Taken together, this study may contribute to future progress in finding new approaches to reverse the attenuation of GABAergic neurotransmission induced by stress in the amygdala.

Keywords: amygdala, GABAergic, chronic stress, acute stress, anxiety

\section{INTRODUCTION}

The amygdala is an almond-shaped structure located within the temporal lobes of the brain and it plays a key role in the processing of fearful and unpleasant stimuli (Aroniadou-Anderjaska et al., 2007; Bzdok et al., 2013). Previous studies have demonstrated that amygdala nuclei participate in the storage and retrieval of conditioned fear and fear memory (Sah et al., 2003; Herry et al., 2008; Pape and Pare, 2010). The nuclei of the amygdaloid complex can be grouped, according to their embryological origins, into three subdivisions: the centromedial, the cortical, and the basolateral complexes groups (Knapska et al., 2007; Spampanato et al., 2011). These are functionally relevant subdivisions with a little bit of difference. Different nuclei within the amygdala appear to process diverse aspects of stress. The basolateral nucleus (BLA) is a cortical-like structure located in the dorsal amygdala and is involved in the regulation of behavioral and physiological stress responses (Bhatnagar et al., 2004). The central amygdala (CeA) has also been reported to play a crucial role in physiological responses to stressors, such as fearful stimuli, stressful stimuli, and some drug-related stimuli (Gilpin et al., 2015). In addition, accumulating evidence suggests that a key subdivision of the extended amygdala, named the bed nucleus of the stria terminalis (BNST), is involved in anxiety and stress (Li et al., 2012).

The networks of $\gamma$-aminobutyric acid-ergic (GABAergic) interneurons in the amygdala are very important components of the brain's inhibitory circuits (Stefanits et al., 2018). This neurotransmitter is necessary for keeping a balance between neuronal excitation and inhibition

Abbreviations: BLA, basolateral nucleus; BNST, stria terminalis; CeA, central amygdala; DEX, dexamethasone; GABA, $\gamma$-aminobutyric acid; GAD, glutamic acid decarboxylase; HPA, hypothalamic-pituitary-adrenal; LA, lateral amygdala; PND, postnatal days. 
(Klausberger and Somogyi, 2008). The BLA contains both glutamatergic principal neurons and GABAergic interneurons (Bhatnagar et al., 2004). The glutamatergic neurons are firmly regulated by a comparatively small population of GABAergic inhibitory neurons (Prager et al., 2016). Destruction of GABAergic inhibition in the BLA can cause behavioral hyperexcitability, such as increased anxiety and depression, emotional dysregulation, and development of seizure activity (Prager et al., 2016). The CeA serves as a major output nucleus of the amygdala by converging inputs from the BLA (Li et al., 2017). In contrast with the BLA, the CeA is only composed of GABAergic neurons (Spampanato et al., 2011). Moreover, the $\mathrm{BLA}$, the CeA, and their connections play a crucial role in the modulation GABAergic control in the amygdala. These amygdala GABAergic neurons are hence adequately positioned to play a central role in the regulation of stress. However, much less is known about the interaction between the amygdala's GABAergic inhibitory system and stress.

Stress is becoming increasingly inevitable in daily life, causing a series of physiological and behavioral responses that significantly alter emotional and behavioral states (Dallman et al., 2003). The way in which stressors impact emotional states depends on a variety of biological and environmental factors (Ulrich-Lai et al., 2015). There are already some studies in experimental animals which investigated the role of the amygdala's GABAergic neuronal system in the regulation of stress. For example, Giachero et al. (2013) showed that threatening stress induced attenuation of GABAergic neurotransmission in BLA, and compelling evidence has shown that wistar kyoto rats presented decreased GABAergic activation in the BLA after a $2.0 \mathrm{~mA}$ shock (Jiao et al., 2011). A reduction in c-Fos expression in GABAergic interneurons of the BLA was found in postweaning rats who had been subjected to social isolation (Lukkes et al., 2012). Wang GY demonstrated that chronic or acute administration of dexamethasone (DEX) upregulates GABA release and GABAergic neuronal spiking in the amygdala (Wang et al., 2016). Liu ZP demonstrated that both chronic mild stress and unpredictable stress leads to an everlasting loss of tonic $\mathrm{GABA}_{\mathrm{A}}$ receptor current in the projection neurons of the LA (Liu et al., 2014). These studies indicate the direct relationship between stress and GABAmodulation in the amygdala. We conducted a systematic review combining both preclinical and clinical evidence to evaluate how stress may influence the GABAergic system in the amygdala.

\section{FUNCTION AND STRUCTURE OF GABA AND GABA RECEPTORS}

GABA is a crucial inhibitory neurotransmitter of the brain and is the primary neurotransmitter of at least one-third of all central nervous system neurons (Bloom and Iversen, 1971). The classes of GABA receptors include $G_{A B A}, G A B A_{B}$, and $\mathrm{GABA}_{\mathrm{A}}$-rho (formerly considered $\mathrm{GABA}_{\mathrm{C}}$ ) receptors (Olsen and Sieghart, 2008, 2009). GABA $_{A}$ and GABA $_{C}$ belong to the super family of pentameric ligand-gated ion channels (Enz, 2001). The $\mathrm{GABA}_{\mathrm{A}}$ receptor is composed of five transmembrane protein subunits including two $\alpha$ subunits, two $\beta$ subunits, and one $\gamma$ subunit (Sieghart and Sperk, 2002). Heterooligomeric $\mathrm{GABA}_{C}$ receptors are composed of three $\mathrm{GABA}_{\mathrm{C}}$ receptor $\rho$ subunits $(\rho 1, \rho 2$, and $\rho 3)(E n z, 2001)$. $G_{A B A}$ receptors are made up of $\mathrm{GABA}_{\mathrm{B} 1}$ and $\mathrm{GABA}_{\mathrm{B} 2}$ subunits (Jiang et al., 2012). Ionotropic $\mathrm{GABA}_{\mathrm{A}}$ and $\mathrm{GABA}_{\mathrm{C}}$ receptors' subunits surround a chloride channel. The metabotropic $\mathrm{GABA}_{\mathrm{B}}$ receptor is coupled to $\mathrm{G}$-proteins and operates by modulating calcium or potassium channels (Enz and Cutting, 1998). GABA A receptors produce a rapid inhibition (Sieghart, 2006), while $\mathrm{GABA}_{\mathrm{B}}$ receptors are coupled with $\mathrm{G}$-proteins to produce slow and prolonged inhibitory responses (Bowery, 2010). GABA $\mathrm{C}$ receptors are more highly localized in axon terminals of bipolar cells compared to GABA $_{A}$ receptors (Enz and Cutting, 1998; McCall et al., 2002). Activation of $\mathrm{GABA}_{\mathrm{A}}$ receptors can cause a massive increase in chloride conductance through the cell membrane (Mody and Pearce, 2004). Furthermore, low concentrations of GABA can persistently activate extrasynaptic $\mathrm{GABA}_{\mathrm{A}}$ receptors and cause a sustaining inhibitory state, meaning that the neuron will not present a normal response to excitatory stimuli (Farrant

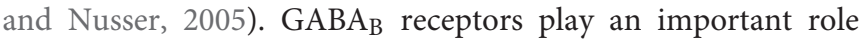
in regulating pre- and postsynapses ( $\mathrm{Xu}$ et al., 2014). It is recognized that $G_{A B A}$ receptors have an influence on the activity and signaling of glutamate receptors both physiologically and pathologically (Kantamneni, 2015). Some studies have suggested that $\mathrm{GABA}_{\mathrm{C}}$ receptors are involved in sleep-waking conduction (Arnaud et al., 2001), emotion and memory (Chebib et al., 2009), apoptosis (Yang et al., 2003), and hormone release in the pituitary (Boue-Grabot et al., 2000). Known GABA $_{C}$ receptor binding proteins do not interact with other types of GABA receptors, implying that $\mathrm{GABA}_{\mathrm{C}}$ receptors have unique pharmacological and physical characteristics (Enz, 2001).

\section{GABAergic CONTROL OF THE AMYGDALA}

As we mentioned above, the amygdala is composed of a number of distinct nuclei including BLA, lateral amygdala (LA), CeA and a key subdivision of the extended amygdala, BNST. The different distribution of GABA is accompanied by various functions in each sub nuclei of amygdaloid complex. Major afferent signals from the medial prefrontal cortex reach the amygdala mainly via the BLA and LA, while efferent signals tend to originate through the CeA (Etkin, 2010). Inhibitory GABAergic neurons project from the $\mathrm{CeA}$ to the hypothalamus and brainstem (Jongen-Rêlo and Amaral, 1998). The amygdala is inhibited by the cortex through the activation of local GABAergic interneurons. In addition, this inhibition is significantly decreased when dopamine is released during heightened emotional states (Mcdonald et al., 1996; Dallman et al., 2003; Pinto and Sesack, 2008). The modulation of emotional responses by the BLA is mainly determined by the balance of excitatory and inhibitory inputs to its dominated neurons which are tightly controlled by GABAergic interneurons (Równiak et al., 2017). As mentioned above, the GABAergic neurons of the amygdala modulate activation of the CeA via 


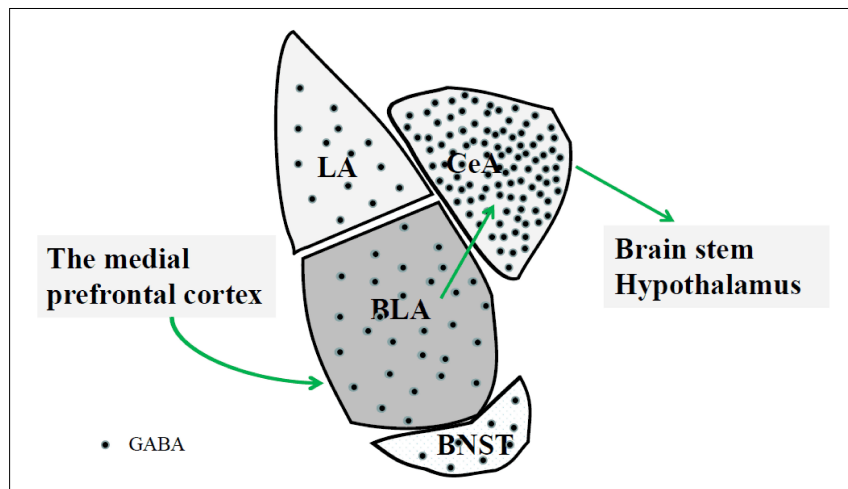

FIGURE 1 | The medial prefrontal cortex can affect BLA GABAergic system. The BLA neurons indirectly project to the CeA via GABAergic interneurons. Projections from CeA mainly target to the hypothalamus and brainstem involved in physiological and behavioral responses to stress. BLA, basolateral nucleus; CeA, central amygdala; BNST, bed nucleus of the stria terminalis; LA, lateral amygdala.

projections from the BLA (Nuss, 2015). Optogenetic techniques selectively isolate distinct neural circuits and help us in the identification of novel brain pathways. Sparta et al. reported that photostimulation of BNST efferents resulted in a behavioral phenotype of the anxiety-like state (Sparta et al., 2013). Figure 1 shows a schematic of the GABA distribution and the projections in each sub nuclei of amygdaloid complex. The GABA synthetic enzyme glutamic acid decarboxylase (GAD) 65 and a second GAD isozyme, GAD67, are important components involved in the activity-dependent modulation of the amygdala's GABAergic system (Müller et al., 2015). Some animal experiments have indicated that administration of GABA receptor agonists or antagonists into the amygdala can influence the concentration of GABA (Sanders and Shekhar, 1995; Barbalho et al., 2009). These have included GABAergic agonists such as benzodiazepines (Sigel and Lüscher, 2011), Zol (Alò et al., 2015), muscimol (Jasnow and Huhman, 2001; Liu et al., 2009), diazepam, and abecarnil (Eva et al., 2004). GABAergic antagonists have included baclofen (Gorsane et al., 2012), bicuculline (Liu et al., 2009), and FG7124 (Eva et al., 2004; Lukkes et al., 2012). Benzodiazepines, Zol, diazepam, and abecarnil bind the subunits of $\mathrm{GABA}_{\mathrm{A}}$ receptors, and this binding increases the probability of ion channel opening in the presence of GABA (Eva et al., 2004; Alò et al., 2015; Fast and McGann, 2017). On the other hand, baclofen competes with GABA for the same sites on $G_{A B A}$ receptors in the amygdala. It has been proposed that these could be helpful in the therapy of stress-induced disorders (Gorsane et al., 2012).

\section{TYPES OF STRESS}

Stress is our body's way of responding to a variety of demands or threats, and affects many bodily functions, such as metabolic, psychological, and behavioral functions. Stress management can be complicated and difficult to understand because it is influenced by many variables, such as the chronicity, predictability and severity of stress (Nalivaiko, 2011; Steptoe and
Kivimäki, 2012; Herman, 2013). Different classification methods divide stress into different types. Stress can be roughly divided into social and non-social (physical) stress (Lee et al., 2016). There are already some reports studying different types of nonsocial stress in rodents, including restraint stress (Lee et al., 2016), forced swim stress (Suarez-Roca et al., 2008), prenatal stress exposure (Lee et al., 2016) and elevated platform stress (Sickmann et al., 2015). Rodent studies on social stress have included social defeat-induced stress (Rutherford et al., 2014), social mixing stress (Jarvis et al., 2006), and social crowdedness stress (Sachser et al., 2011). Some animal studies looking at the influence of predictable and unpredictable stressor stimuli showed that the latter induces more pronounced behavioral and physiological results (Bassett et al., 1973; Magariños and McEwen, 1995; Marin et al., 2007; Flak et al., 2012; Kopp et al., 2013; Smith et al., 2013). However, most studies do not make a clear distinction between predictable and unpredictable stressor stimuli and focus more on the duration of the stimulus. Furthermore, there have been some reports showing that acute and chronic aversive stimuli cause very different responses (Nalivaiko, 2011; Herman, 2013). Based on the above reasons, we have divided stress into two types: acute stress and chronic stress. There have been many studies demonstrating that various types of stress are involved in the control of the amygdala's GABAergic neurons. These include acute forced swim stress (Bedse et al., 2015), prenatal stress (Ehrlich et al., 2015), chronic unpredictable restraint stress (Ortiz et al., 2015), and posttraumatic stress (Müller et al., 2015). Stress can also derive from withdraw infections of drugs or continuous alcohol abuse (Stephens and Wand, 2012). Agentia administration can influence the hypothalamic-pituitary-adrenal (HPA) axis and we have categorized it as acute or chronic stress depending on its method of administration. Likewise, we categorized chronic ethanol exposure as chronic stress and acute ethanol exposure as acute stress. We will describe these in two categories according to the classification factors mentioned above.

\section{INFLUENCE OF THE GABAergic SYSTEM IN AMYGDALA RESPONSES TO STRESS}

Severe acute stress and chronic stress can influence the amygdala's stress response through three main regulatory systems: the serotonergic system (Hernández et al., 2016), the catecholaminergic system (Wang et al., 2016), and the HPA axis (Wisłowska-Stanek et al., 2013). Here, we highlight the influence of the GABAergic system in amygdala responses to stress. As we described above, the GABAergic responses to stress also involve many subnuclei of the amygdala, such as the BLA, CeA, LA, and BNST (Zuloaga et al., 2012). In addition, stress influence amygdala's GABAergic transmission in a cell type- and projection- specific way. Accumulating evidence demonstrates that BLA projections to the CeA distinctly alter motivated behavior (Beyeler et al., 2018). Stress induced persistent anxiety via the extra-amygdala septohypothalamic circuit (Anthony et al., 2014). Liu et al. (2018) found that harmine potentiates the GABAergic transmission onto BLA projection neurons. 
TABLE 1 | Influence of the GABAergic system in amygdala responses to stress.

\begin{tabular}{|c|c|c|c|c|}
\hline & Types of stress & Regions & Changes in GABAergic system & References \\
\hline \multirow[t]{9}{*}{ Acute } & Forced swimming & $B L A$ & $\begin{array}{l}\text { Activation of GPR30 increased the inhibitory synaptic } \\
\text { transmission }\end{array}$ & Tian et al., 2013 \\
\hline & & $B L A$ & Promote GABAergic transmission & Feng et al., 2013 \\
\hline & & BLA & $\begin{array}{l}\text { Disrupted the cannabinoid receptor type 1-associated } \\
\text { modulation of the GABAergic system }\end{array}$ & Bedse et al., 2015 \\
\hline & Restraint stress & $\mathrm{CeA}$ & Elevate baseline GABAergic responses & Ciccocioppo et al., 2014 \\
\hline & Maternal separation & CeA & $\begin{array}{l}\text { Increase in the density V1a transcripts of GABAergic } \\
\text { neurons }\end{array}$ & Hernández et al., 2016 \\
\hline & & $B L A$ & $\begin{array}{l}\text { Decrease c-Fos expression in a subset of GABAergic } \\
\text { interneurons }\end{array}$ & Lukkes et al., 2012 \\
\hline & Glucocorticoid administration & BLA & Suppress spontaneous GABAergic synaptic currents & Di et al., 2016 \\
\hline & DEX administration & & $\begin{array}{l}\text { Upregulate GABA release and GABAergic neuronal } \\
\text { spiking }\end{array}$ & Wang et al., 2016 \\
\hline & Ethanol consumption & BLA & Increase GABAergic transmission & Varodayan et al., 2017 \\
\hline \multirow[t]{11}{*}{ Chronic } & Water-deprivation & CeA & $\begin{array}{l}\text { Increase in the density V1a transcripts of GABAergic } \\
\text { neurons }\end{array}$ & Hernández et al., 2016 \\
\hline & Chronic unpredictable & CeA & Regulation of GABAA receptors & Alò et al., 2015 \\
\hline & & CeA and BNST & Promote GABAergic transmission & Partridge et al., 2016 \\
\hline & & CeA & Down-regulation of GAD65 expression & Ortiz et al., 2015 \\
\hline & Corticosterone administration & LA and CeA & Decreased GABAA $\alpha-2$ subunit density & Skórzewska et al., 2015 \\
\hline & DEX administration & & $\begin{array}{l}\text { Increase cleaved caspase-3 and GABAergic } \\
\text { calcium-binding protein }\end{array}$ & Zuloaga et al., 2011 \\
\hline & & & Enhanced the responsiveness of GABA receptors & Wang et al., 2016 \\
\hline & Ethanol consumption & $B L A$ & $\begin{array}{l}\text { Disrupted the cannabinoid receptor type 1-associated } \\
\text { modulation of the GABAergic system }\end{array}$ & Varodayan et al., 2017 \\
\hline & Prenatal stress & & $\begin{array}{l}\text { Influenced the chloride transporters } \mathrm{K}-\mathrm{Cl} \text { cotransporter } \\
2, \mathrm{Na}-\mathrm{K}-\mathrm{Cl} \text { cotransporter } 1\end{array}$ & Ehrlich et al., 2015 \\
\hline & Peripuberty stress & $\llcorner A, B\llcorner A$, and CeA & $\begin{array}{l}\text { Decrease in the expression of GAD and GABAA } \\
\text { receptor subunits }\end{array}$ & Tzanoulinou et al., 2014 \\
\hline & & & Regulation of the GABAA receptor subunits & Jacobson-Pick and Richter-Levin, 2012 \\
\hline
\end{tabular}

BLA, basolateral nucleus; CeA, central amygdala; BNST, bed nucleus of the stria terminalis; LA, lateral amygdala; GPR30, G-protein-coupled receptor 30; GABA, $\gamma$-aminobutyric acid; BLA, basolateral nucleus; GAD, glutamic acid decarboxylase.

However, only partially understood about the role of neuronal components of these regions in amygdala circuits. For instance, $\mathrm{Yu}$ et al. (2017) showed that PKC- $\delta$ positive lateral CeA neurons were "fear-on" neurons as they convey aversive unconditioned stimulus signals. Administration of CRF into the BLA induced pronounced increases in cFos-ir in the CaMKII-ir population and altered the activity of GABAergic interneurons (Rostkowski et al., 2013). The relationship between GABA amygdalar system and stress is complex. Depending on the duration of stress, more influence of the GABAergic system in amygdala responses to acute stress and chronic stress will be discussed separately below.

\section{GABAergic Control of Amygdala Responses to Acute Stress}

Restraint and forced swimming are the most common form of acute stress. Tian et al. (2013) found some new targets that reduce the amygdala's response to these acute stresses. G-protein-coupled receptor 30, one of the estrogen receptors, is a novel membrane receptor that is highly expressed in the BLA. Additionally, G-protein-coupled receptor 30 expression in the amygdala was substantially increased after acute stress and this correlated with anxiety-like behaviors. Moreover, the
G-protein-coupled receptor 30 agonist blocked the downregulation of $\mathrm{GABA}_{\mathrm{A}}$ receptors (Tian et al., 2013). Feng et al. found another potential therapy for regulate stress is motilin which can weaken anxiety-like behavior in rats after they have been subjected to forced swimming. Whole-cell recordings from amygdala slices revealed that motilin depolarized the interneurons and promoted GABAergic transmission in the BLA (Feng et al., 2013). Bedse et al. (2015) found that pretreatment with the cannabinoid receptor type 1 receptor antagonist rimonabant blocked the effect of the fatty acid amide hydrolase inhibitor (URB597) on GABA release in the BLA of animals subjected to the acute swim stress. In rats subjected to restraint stress, acute application of corticotropin releasing factor significantly increased inhibitory postsynaptic potentials in the CeA (Ciccocioppo et al., 2014).

Neonatal maternal separation stress is instantaneous but induces long-lasting alterations in emotional behaviors. It was reported that adult rats that had experienced neonatal maternal separation presented an increase in the density of arginine-vasopressin innervation in the amygdala. Furthermore, V1a arginine-vasopressin receptor mRNA was only found in GABAergic neurons, demonstrated by complete co-localization of V1a transcripts in CeA neurons expressing GAD transcripts 
(Hernández et al., 2016). Another study demonstrated that postweaning social isolation decreased c-Fos expression in a subset of GABAergic interneurons in the BLA of adult female rats (Lukkes et al., 2012).

It is worth noting that the HPA axis can mediate the stress response because it is a neuroendocrine system. Some researchers looked at the effects of rapid glucocorticoid-induced acute stress in the rat BLA. Glucocorticoid administrated to amygdala slices produced a rapid, non-reversible suppression of spontaneous GABAergic synaptic currents (Di et al., 2016). The acute administration of glucocorticoid receptor agonist DEX also upregulated GABA release and GABAergic neuronal spiking (Wang et al., 2016).

Acute ethanol consumption increased GABAergic transmission via the mechanisms involved in both presynaptic and postsynaptic functioning (Varodayan et al., 2017). Although, ethanol facilitated GABAergic transmission in the brain, the activation of cannabinoid receptor type 1 inhibited this effect (Di et al., 2016; Varodayan et al., 2017).

\section{GABAergic Control of Amygdala Responses to Chronic Stress}

Water-deprivation is a kind of chronic stress. Water-deprivation for $24 \mathrm{~h}$ in rats enhanced anxiety correlative behavior measured with the elevated plus maze test. This effect was reproduced by bilateral micro infusion of arginine-vasopressin into the CeA. Chronic stress induced by either water-deprivation or argininevasopressin infusion was reversed by CeA infusion of a V1a antagonist (Hernández et al., 2016).

In another chronic unpredictable stress model, hamsters were casually subjected to one of three pre-prepared stressful circumstances: food or water deprivation, forced swim test, and endurance in a cold room. Injection of the $\alpha 1 \mathrm{GABA}_{\mathrm{A}}$ receptor subunit agonist (Zol) into the CeA changed elevated plus maze performances (Alò et al., 2015). Chronic, unpredictable stress increased the amplitude of evoked induced pluripotent stem cells and the connectivity between corticotropin releasing factor positive neurons in the CeA and BNST (Partridge et al., 2016). In male rats with chronic unpredictable restraint stress, GAD65 expression in the amygdala negatively correlated with radial arm water maze performances on day 1 in rats subjected to unpredictable restraint stress (Ortiz et al., 2015). Importantly, baseline CeA GABAergic responses were elevated in restrained rats compared with unrestrained rats.

Rats subjected to repeated corticosterone administration showed an increase in anxiety-like behavior, examined using the open field test. The behavioral effects caused by corticosterone injections may because of increased expression of c-Fos in the LA and CeA nuclei of the amygdala and decreased $\mathrm{GABA}_{\mathrm{A}} \alpha-2$ subunit density in the CeA of these rats (Skórzewska et al., 2015). These findings are consistent with those of another study (Lussier et al., 2013). Liu et al. (2014) suggested that a lasting loss of tonic but not phasic $\mathrm{GABA}_{\mathrm{A}}$ receptor currents severely contributes to the prolonged amygdala disinhibition observed after chronic stress. Injection of glucocorticoids during early development may lead to long-term variations in brain function and behavior. The glucocorticoid receptor agonist DEX plays a role in emotion. Postnatal DEX administration in animals caused an increase in cleaved caspase- 3 and the expression of a GABAergic calciumbinding protein phenotype in the amygdala (Zuloaga et al., 2011). DEX administration mainly caused a decrease in the number of calretinin immunoreactive cells in the LA of adult female offspring, but no differences were observed in the BLA (Zuloaga et al., 2012). The chronic administration of DEX upregulated GABA release and GABAergic neuronal intensification, and also enhanced the responsiveness of GABA receptors (Wang et al., 2016). Peroxisome proliferator-activated receptors are members of the nuclear hormone receptor family. Peroxisome proliferatoractivated receptor agonists such as fenofibrate and tesaglitazar, when administered to mice subjected to a free access two-bottle choice drinking paradigm, provoked a strong brain neuronal signature and targeted a small group of GABAergic interneurons in the amygdala (Ferguson et al., 2014).

Alcohol can cause the dysfunction of the cannabinoid receptor type 1 in many ways. However, a study showed that chronic alcohol exposure disrupted the cannabinoid receptor type 1associated modulation of the GABAergic system in the rat basolateral amygdala (Varodayan et al., 2017).

Commonly, the prenatal period, infancy, pubescence, and adolescence are critical periods in which animals are more sensitive to stressors than usual (Charmandari et al., 2003, 2012). Ehrlich et al. used a prenatal stress model of maternal depression to test the changes of GABAergic neurotransmission in the amygdala. They found that rats exposed to this stress in utero had increased anxiety-like behavior in adulthood. Exposure to prenatal stress also deeply influenced the expression of the chloride transporters $\mathrm{K}-\mathrm{Cl}$ cotransporter 2 and $\mathrm{Na}-\mathrm{K}-\mathrm{Cl}$ cotransporter 1 in the amygdala, indicating that stress regulates GABAergic function (Ehrlich et al., 2015). Tzanoulinou et al. showed that peripuberty stress may cause a decrease in the expression of $\mathrm{GAD}$ and $\mathrm{GABA}_{\mathrm{A}}$ receptor subunits in all amygdala nuclei present in adult rats (Tzanoulinou et al., 2014). During the juvenile period, rats are particularly vulnerable to stressors. Animals were subjected to a juvenile variable stressor regimen at 27-29 postnatal days (PND), including PND-acute swim stress, PND-elevated platform stress, and PND-restraint stress. The stress-induced regulation of the $\mathrm{GABA}_{\mathrm{A}}$ receptor subunits was specifically evident in the amygdala (Jacobson-Pick and RichterLevin, 2012).

Table 1 summarizes some of the interaction between GABAergic transmission in particular regions of the amygdala and particular types of stress. BLA and CeA seems to be the most relevant regions of GABAergic neurotransmission in the amygdala.

\section{GABAergic CONTROL OF THE AMYGDALA AND RELEVANCE TO NEUROPSYCHIATRIC DISEASES}

There may be an interaction between stress and neuropsychiatric diseases. A number of studies have demonstrated this interaction (Schneiderman et al., 2005). Animal studies showed that exposure 
to acute or chronic stress can induce morphological and functional changes in amygdala. These changes in amygdala can cause individual susceptibility to anxiety disorders (Sandi and Richter-Levin, 2009). Chronic stress generally cause the development of psychological problems such as delusions (Kingston and Schuurmans-Stekhoven, 2016), depression (Norman and Malla, 1993; Corcoran et al., 2003; Hammen, 2005), and anxiety (Schlotz et al., 2011; Saveanu and Nemeroff, 2012). There are also reports that chronic stress is possibly a major cause of depression, and that acute severe stress leads to anxiety (Wang et al., 2016). Khansari et al. demonstrated that chronic stress is linked to Alzheimer's disease (Khansari et al., 1990). In fact, GABAergic control of the amygdala is mostly relevant to anxiety. Some animal researches have shown that administration of corticosterone into the CeA can induce anxiety-like behavior. This animal model imitate the depressed effect of chronic stress on GABAergic tonic inhibition in LA (Myers et al., 2005). There are also some studies that show an association between the amygdala's GABA interneuronal network and alcohol addiction (Nie et al., 2004, 2009; Bajo et al., 2008). Aroniadou et al. reported a key role of the amygdala's GABAergic control in epilepsy. The stress-induced damage to the noradrenergic system, promoting GABA release in the BLA, may underlie the stress-induced exacerbation of seizure activity in epileptic patients (Aroniadou-Anderjaska et al., 2007). However, more recent studies have suggested that stress itself does not

\section{REFERENCES}

Alò, R., Mele, M., Avolio, E., Fazzari, G., and Canonaco, M. (2015). Distinct amygdalar AMPAergic/GABAergic mechanisms promote anxiolitic-like effects in an unpredictable stress model of the hamster. J. Mol. Neurosci. 55, 541-551. doi: 10.1007/s12031-014-0386-4

Anthony, T. E., Dee, N., Bernard, A., Lerchner, W., Heintz, N., and Anderson, D. J. (2014). Control of stress-induced persistent anxiety by an extra-amygdala septohypothalamic circuit. Cell 156, 522-536. doi: 10.1016/j.cell.2013.12.040

Arnaud, C., Gauthier, P., and Gottesmann, C. (2001). Study of a GABAC receptor antagonist on sleep-waking behavior in rats. Psychopharmacology 154, 415-419.

Aroniadou-Anderjaska, V., Qashu, F., and Braga, M. F. (2007). Mechanisms regulating GABAergic inhibitory transmission in the basolateral amygdala: implications for epilepsy and anxiety disorders. Amino Acids 32, 305-315. doi: 10.1007/s00726-006-0415-x

Bajo, M., Cruz, M. T., Siggins, G. R., Messing, R., and Roberto, M. (2008). Protein kinase $\mathrm{C}$ epsilon mediation of CRF- and ethanol-induced GABA release in central amygdala. Proc. Natl. Acad. Sci. U.S.A. 105, 8410-8415. doi: 10.1073/ pnas.0802302105

Barbalho, C. A., Nunes-de-Souza, R. L., and Canto-de-Souza, A. (2009). Similar anxiolytic-like effects following intra-amygdala infusions of benzodiazepine receptor agonist and antagonist: evidence for the release of an endogenous benzodiazepine inverse agonist in mice exposed to elevated plus-maze test. Brain Res. 1267, 65-76. doi: 10.1016/j.brainres.2009.02.042

Bassett, J. R., Cairncross, K. D., and King, M. G. (1973). Parameters of novelty, shock predictability and response contingency in corticosterone release in the rat. Physiol. Behav. 10, 901-907.

Bedse, G., Romano, A., Tempesta, B., Lavecchia, M. A., Pace, L., Bellomo, A., et al. (2015). Inhibition of anandamide hydrolysis enhances noradrenergic and GABAergic transmission in the prefrontal cortex and basolateral amygdala of rats subjected to acute swim stress. J. Neurosci. Res. 93, 777-787. doi: 10.1002/ jnr.23539

Beyeler, A., Chang, C. J., Silvestre, M., Lévêque, C., Namburi, P., Wildes, C. P., et al. (2018). Organization of valence-encoding and projection-defined neurons enhance the risk of developing a disorder, but that it is the perception that stress affects health that is destructive (Keller et al., 2012). For instance, when humans are exposed to chronic stress, steady changes in their physiological and emotional state are the most involved in changes that could lead to illness (Tsoory et al., 2007; Jeronimus et al., 2014). More clinical evidence is needed to better understand stress and to be able to attenuate the effects of stress. This study provides a novel understanding of the interaction between GABAergic transmission in particular regions of the amygdala and particular types of stress.

\section{AUTHOR CONTRIBUTIONS}

FJ, GY, WY, SG, JL, and BL participated in the discussion of the paper. SG, JL, and BL provided the critical revisions. All authors approved the final version of the manuscript for submission.

\section{FUNDING}

The work was supported by the Natural Science Foundation of China (NSFC). Grant Nos. 31571126, 31300850, and 81772291 and Jilin Science and Technology Agency funding. Grant Nos. $20180414051 \mathrm{GH}$ and $20180414050 \mathrm{GH}$, and the Ministry of Science and Technology fund. Grant No. 2018YFC1311600.

in the basolateral amygdala. Cell Rep. 22, 905-918. doi: 10.1016/j.celrep.2017. 12.097

Bhatnagar, S., Vining, C., and Denski, K. (2004). Regulation of chronic stressinduced changes in hypothalamic-pituitary-adrenal activity by the basolateral amygdala. Ann. N. Y. Acad. Sci. 1032, 315-319. doi: 10.1196/annals. 1314.050

Bloom, F. E., and Iversen, L. L. (1971). Localizing 3H-GABA in nerve terminals of rat cerebral cortex by electron microscopic autoradiography. Nature 229, $628-630$.

Boue-Grabot, E., Taupignon, A., Tramu, G., and Garret, M. (2000). Molecular and electrophysiological evidence for a GABAc receptor in thyrotropin-secreting cells. Endocrinology 141, 1627-1632. doi: 10.1210/endo.141.5.7476

Bowery, N. G. (2010). Historical perspective and emergence of the GABAB receptor. Adv. Pharmacol. 58, 1-18. doi: 10.1016/S1054-3589(10) 58001-3

Bzdok, D., Laird, A. R., Zilles, K., Fox, P. T., and Eickhoff, S. B. (2013). An investigation of the structural, connectional, and functional subspecialization in the human amygdala. Hum. Brain Mapp. 34, 3247-3266. doi: 10.1002/hbm. 22138

Charmandari, E., Achermann, J. C., Carel, J. C., Soder, O., and Chrousos, G. P. (2012). Stress response and child health. Sci. Signal. 5:mr1. doi: 10.1126/ scisignal.2003595

Charmandari, E., Kino, T., Souvatzoglou, E., and Chrousos, G. P. (2003). Pediatric stress: hormonal mediators and human development. Horm. Res. 59, 161-179. doi: $10.1159 / 000069325$

Chebib, M., Hinton, T., Schmid, K. L., Brinkworth, D., Qian, H., Matos, S., et al. (2009). Novel, potent, and selective GABAC antagonists inhibit myopia development and facilitate learning and memory. J. Pharmacol. Exp. Ther. 328, 448-457. doi: 10.1124/jpet.108.146464

Ciccocioppo, R., de Guglielmo, G., Hansson, A. C., Ubaldi, M., Kallupi, M., Cruz, M. T., et al. (2014). Restraint stress alters nociceptin/orphanin FQ and CRF systems in the rat central amygdala: significance for anxietylike behaviors. J. Neurosci. 34, 363-372. doi: 10.1523/JNEUROSCI.240013.2014 
Corcoran, C., Walker, E., Huot, R., Mittal, V., Tessner, K., Kestler, L., et al. (2003). The stress cascade and schizophrenia: etiology and onset. Schizophr. Bull. 29, 671-692.

Dallman, M. F., Pecoraro, N., Akana, S. F., La Fleur, S. E., Gomez, F., Houshyar, H., et al. (2003). Chronic stress and obesity: a new view of "comfort food". Proc. Natl. Acad. Sci. U.S.A. 100, 11696-11701. doi: 10.1073/pnas. 1934666100

Di, S., Itoga, C. A., Fisher, M. O., Solomonow, J., Roltsch, E. A., Gilpin, N. W., et al. (2016). Acute stress suppresses synaptic inhibition and increases anxiety via endocannabinoid release in the basolateral amygdala. J. Neurosci. 36, 8461-8470. doi: 10.1523/JNEUROSCI.2279-15.2016

Ehrlich, D. E., Neigh, G. N., Bourke, C. H., Nemeth, C. L., Hazra, R., Ryan, S. J., et al. (2015). Prenatal stress, regardless of concurrent escitalopram treatment, alters behavior and amygdala gene expression of adolescent female rats. Neuropharmacology 97, 251-258. doi: 10.1016/j.neuropharm.2015.05.012

Enz, R. (2001). GABA(C) receptors: a molecular view. Biol. Chem. 382, 1111-1122. doi: 10.1515/BC.2001.141

Enz, R., and Cutting, G. R. (1998). Molecular composition of GABAC receptors. Vision Res. 38, 1431-1441.

Etkin, A. (2010). Functional neuroanatomy of anxiety: a neural circuit perspective. Curr. Top. Behav. Neurosci. 2, 251-277.

Eva, C., Mele, P., Oberto, A., Panzica, G., Pisu, M. G., and Serra, M. (2004). Neuroanatomical and pharmacological evidence for a functional interaction between GABAergic and NPY-Y1 transmission in the amygdala of Y1R/LacZ transgenic mice. Crit. Rev. Neurobiol. 16, 33-41.

Farrant, M., and Nusser, Z. (2005). Variations on an inhibitory theme: phasic and tonic activation of GABA(A) receptors. Nat. Rev. Neurosci. 6, 215-229. doi: $10.1038 /$ nrn 1625

Fast, C. D., and McGann, J. P. (2017). Amygdalar gating of early sensory processing through interactions with locus coeruleus. J. Neurosci. 37, 3085-3101. doi: 10.1523/JNEUROSCI.2797-16.2017

Feng, B., Liu, J. C., Zhang, J., Ozaki, K., Guo, Y. Y., Yi, D. H., et al. (2013). Anxiolytic actions of motilin in the basolateral amygdala. Mol. Neurobiol. 47, 892-902. doi: 10.1007/s12035-012-8383-5

Ferguson, L. B., Most, D., Blednov, Y. A., and Harris, R. A. (2014). PPAR agonists regulate brain gene expression: relationship to their effects on ethanol consumption. Neuropharmacology 86, 397-407. doi: 10.1016/j.neuropharm. 2014.06.024

Flak, J. N., Solomon, M. B., Jankord, R., Krause, E. G., and Herman, J. P. (2012). Identification of chronic stress-activated regions reveals a potential recruited circuit in rat brain. Eur. J. Neurosci. 36, 2547-2555. doi: 10.1111/j.1460-9568. 2012.08161.x

Giachero, M., Calfa, G. D., and Molina, V. A. (2013). Hippocampal structural plasticity accompanies the resulting contextual fear memory following stress and fear conditioning. Learn. Mem. 20, 611-616. doi: 10.1101/lm.031724.113

Gilpin, N. W., Herman, M. A., and Roberto, M. (2015). The central amygdala as an integrative hub for anxiety and alcohol use disorders. Biol. Psychiatry 77, 859-869. doi: 10.1016/j.biopsych.2014.09.008

Gorsane, M. A., Kebir, O., Hache, G., Blecha, L., Aubin, H. J., Reynaud, M., et al. (2012). Is baclofen a revolutionary medication in alcohol addiction management? Review and recent updates. Subst. Abus. 33, 336-349. doi: 10. 1080/08897077.2012.663326

Hammen, C. (2005). Stress and depression. Annu. Rev. Clin. Psychol. 1, 293-319. doi: 10.1146/annurev.clinpsy.1.102803.143938

Herman, J. P. (2013). Neural control of chronic stress adaptation. Front. Behav. Neurosci. 7:61. doi: 10.3389/fnbeh.2013.00061

Hernández, V. S., Hernández, O. R., de la Mora, M. P., Gómora, M. J., Fuxe, K., Eiden, L. E., et al. (2016). Hypothalamic vasopressinergic projections innervate central amygdala GABAergic neurons: implications for anxiety and stress coping. Front. Neural Circuits 10:92. doi: 10.3389/fncir.2016.00092

Herry, C., Ciocchi, S., Senn, V., Demmou, L., Müller, C., and Lüthi, A. (2008). Switching on and off fear by distinct neuronal circuits. Nature 454, 600-606. doi: $10.1038 /$ nature 07166

Jacobson-Pick, S., and Richter-Levin, G. (2012). Short- and long-term effects of juvenile stressor exposure on the expression of GABAA receptor subunits in rats. Stress 15, 416-424. doi: 10.3109/10253890.2011.634036

Jarvis, S., Moinard, C., Robson, S. K., Baxter, E., Ormandy, E., Douglas, A. J., et al. (2006). Programming the offspring of the pig by prenatal social stress: neuroendocrine activity and behaviour. Horm. Behav. 49, 68-80. doi: 10.1016/j. yhbeh.2005.05.004

Jasnow, A. M., and Huhman, K. L. (2001). Activation of GABA(A) receptors in the amygdala blocks the acquisition and expression of conditioned defeat in Syrian hamsters. Brain Res. 920, 142-150.

Jeronimus, B. F., Riese, H., Sanderman, R., and Ormel, J. (2014). Mutual reinforcement between neuroticism and life experiences: a five-wave, 16-year study to test reciprocal causation. J. Pers. Soc. Psychol. 107, 751-764. doi: 10. 1037/a0037009

Jiang, X., Su, L., Zhang, Q., He, C., Zhang, Z., Yi, P., et al. (2012). GABAB receptor complex as a potential target for tumor therapy. J. Histochem. Cytochem. 60, 269-279. doi: 10.1369/0022155412438105

Jiao, X., Pang, K. C., Beck, K. D., Minor, T. R., and Servatius, R. J. (2011). Avoidance perseveration during extinction training in Wistar-Kyoto rats: an interaction of innate vulnerability and stressor intensity. Behav. Brain Res. 221, 98-107. doi: 10.1016/j.bbr.2011.02.029

Jongen-Rêlo, A. L., and Amaral, D. G. (1998). Evidence for a GABAergic projection from the central nucleus of the amygdala to the brainstem of the macaque monkey: a combined retrograde tracing and in situ hybridization study. Eur. J. Neurosci. 10, 2924-2933.

Kantamneni, S. (2015). Cross-talk and regulation between glutamate and GABAB receptors. Front. Cell. Neurosci. 9:135. doi: 10.3389/fncel.2015.00135

Keller, A., Litzelman, K., Wisk, L. E., Maddox, T., Cheng, E. R., Creswell, P. D., et al. (2012). Does the perception that stress affects health matter? The association with health and mortality. Health Psychol. 31, 677-684. doi: 10.1037/a0026743

Khansari, D. N., Murgo, A. J., and Faith, R. E. (1990). Effects of stress on the immune system. Immunol. Today 11, 170-175.

Kingston, C., and Schuurmans-Stekhoven, J. (2016). Life hassles and delusional ideation: scoping the potential role of cognitive and affective mediators. Psychol. Psychother. 89, 445-463. doi: 10.1111/papt.12089

Klausberger, T., and Somogyi, P. (2008). Neuronal diversity and temporal dynamics: the unity of hippocampal circuit operations. Science 321, 53-57. doi: 10.1126/science.1149381

Knapska, E., Radwanska, K., Werka, T., and Kaczmarek, L. (2007). Functional internal complexity of amygdala: focus on gene activity mapping after behavioral training and drugs of abuse. Physiol. Rev. 87, 1113-1173. doi: 10. 1152/physrev.00037.2006

Kopp, B. L., Wick, D., and Herman, J. P. (2013). Differential effects of homotypic vs. Heterotypic chronic stress regimens on microglial activation in the prefrontal cortex. Physiol. Behav. 122, 246-252. doi: 10.1016/j.physbeh.2013.05.030

Lee, Y. A., Kim, Y. J., and Goto, Y. (2016). Cognitive and affective alterations by prenatal and postnatal stress interaction. Physiol. Behav. 165, 146-153. doi: 10.1016/j.physbeh.2016.07.014

Li, B., Ge, T., and Cui, R. (2017). Long-term plasticity in amygdala circuits: implication of CB1-dependent LTD in stress. Mol. Neurobiol. 55, 4107-4114. doi: 10.1007/s12035-017-0643-y

Li, C., Pleil, K. E., Stamatakis, A. M., Busan, S., Vong, L., Lowell, B. B., et al. (2012). Presynaptic inhibition of gamma-aminobutyric acid release in the bed nucleus of the stria terminalis by kappa opioid receptor signaling. Biol. Psychiatry 71, 725-732. doi: 10.1016/j.biopsych.2011.11.015

Liu, W. Z., Huang, B. W., You, W. J., Hu, P., Wang, X. H., Zhang, J. Y., et al. (2018). Harmine enhances GABAergic transmission onto basoamygdala projection neurons in mice. Brain Res. Bull. 137, 294-300. doi: 10.1016/j.brainresbull.2018. 01.004

Liu, X., Yang, L., Wellman, L. L., Tang, X., and Sanford, L. D. (2009). GABAergic antagonism of the central nucleus of the amygdala attenuates reductions in rapid eye movement sleep after inescapable footshock stress. Sleep 32, 888-896.

Liu, Z. P., Song, C., Wang, M., He, Y., Xu, X. B., Pan, H. Q., et al. (2014). Chronic stress impairs GABAergic control of amygdala through suppressing the tonic GABAA receptor currents. Mol. Brain 7:32. doi: 10.1186/1756-6606-7-32

Lukkes, J. L., Burke, A. R., Zelin, N. S., Hale, M. W., and Lowry, C. A. (2012). Post-weaning social isolation attenuates c-Fos expression in GABAergic interneurons in the basolateral amygdala of adult female rats. Physiol. Behav. 107, 719-725. doi: 10.1016/j.physbeh.2012.05.007

Lussier, A. L., Romay-Tallón, R., Caruncho, H. J., and Kalynchuk, L. E. (2013). Altered GABAergic and glutamatergic activity within the rat hippocampus and amygdala in rats subjected to repeated corticosterone administration but 
not restraint stress. Neuroscience 231, 38-48. doi: 10.1016/j.neuroscience.2012. 11.037

Magariños, A. M., and McEwen, B. S. (1995). Stress-induced atrophy of apical dendrites of hippocampal CA $3 \mathrm{c}$ neurons: comparison of stressors. Neuroscience 69, 83-88.

Marin, M. T., Cruz, F. C., and Planeta, C. S. (2007). Chronic restraint or variable stresses differently affect the behavior, corticosterone secretion and body weight in rats. Physiol. Behav. 90, 29-35. doi: 10.1016/j.physbeh.2006.08.021

McCall, M. A., Lukasiewicz, P. D., Gregg, R. G., and Peachey, N. S. (2002). Elimination of the rhol subunit abolishes $\operatorname{GABA}(\mathrm{C})$ receptor expression and alters visual processing in the mouse retina. J. Neurosci. 22, 4163-4174.

Mcdonald, A. J., Mascagni, F., and Guo, L. (1996). Projections of the medial and lateral prefrontal cortices to the amygdala: a Phaseolus vulgaris leucoagglutinin study in the rat. Neuroscience $71,55-75$.

Myers, D. A., Gibson, M., Schulkin, J., and Greenwood Van-Meerveld, B. (2005). Corticosterone implants to the amygdala and type $1 \mathrm{CRH}$ receptor regulation: effects on behavior and colonic sensitivity. Behav. Brain Res. 161, 39-44. doi: 10.1016/j.bbr.2005.03.001

Mody, I., and Pearce, R. A. (2004). Diversity of inhibitory neurotransmission through GABA(A) receptors. Trends Neurosci. 27, 569-575. doi: 10.1016/j.tins. 2004.07.002

Müller, I., Çalışkan, G., and Stork, O. (2015). The GAD65 knock out mouse - a model for GABAergic processes in fear- and stress-induced psychopathology. Genes Brain Behav. 14, 37-45. doi: 10.1111/gbb.12188

Nalivaiko, E. (2011). Animal models of psychogenic cardiovascular disorders: what we can learn from them and what we cannot. Clin. Exp. Pharmacol. Physiol. 38, 115-125. doi: 10.1111/j.1440-1681.2010.05465.x

Nie, Z., Schweitzer, P., Roberts, A. J., Madamba, S. G., Moore, S. D., and Siggins, G. R. (2004). Ethanol augments GABAergic transmission in the central amygdala via CRF1 receptors. Science 303, 1512-1514. doi: 10.1126/science. 1092550

Nie, Z., Zorrilla, E. P., Madamba, S. G., Rice, K. C., Roberto, M., and Siggins, G. R. (2009). Presynaptic CRF1 receptors mediate the ethanol enhancement of GABAergic transmission in the mouse central amygdala. Sci. World J. 9, 68-85. doi: $10.1100 /$ tsw.2009.1

Norman, R. M., and Malla, A. K. (1993). Stressful life events and schizophrenia. I: a review of the research. Br. J. Psychiatry 162, 161-166.

Nuss, P. (2015). Anxiety disorders and GABA neurotransmission: a disturbance of modulation. Neuropsychiatr. Dis. Treat. 11, 165-175. doi: 10.2147/NDT.S58841

Olsen, R. W., and Sieghart, W. (2008). International Union of Pharmacology. LXX. Subtypes of gamma-aminobutyric acid(A) receptors: classification on the basis of subunit composition, pharmacology, and function. Update. Pharmacol. Rev. 60, 243-260. doi: 10.1124/pr.108.00505

Olsen, R. W., and Sieghart, W. (2009). GABA A receptors: subtypes provide diversity of function and pharmacology. Neuropharmacology 56, 141-148. doi: 10.1016/j.neuropharm.2008.07.045

Ortiz, J. B., Taylor, S. B., Hoffman, A. N., Campbell, A. N., Lucas, L. R., and Conrad, C. D. (2015). Sex-specific impairment and recovery of spatial learning following the end of chronic unpredictable restraint stress: potential relevance of limbic GAD. Behav. Brain Res. 282, 176-184. doi: 10.1016/j.bbr.2014.12.051

Pape, H. C., and Pare, D. (2010). Plastic synaptic networks of the amygdala for the acquisition, expression, and extinction of conditioned fear. Physiol. Rev. 90, 419-463. doi: 10.1152/physrev.00037.2009

Partridge, J. G., Forcelli, P. A., Luo, R., Cashdan, J. M., Schulkin, J., Valentino, R. J., et al. (2016). Stress increases GABAergic neurotransmission in CRF neurons of the central amygdala and bed nucleus stria terminalis. Neuropharmacology 107, 239-250. doi: 10.1016/j.neuropharm.2016.03.029

Pinto, A., and Sesack, S. R. (2008). Ultrastructural analysis of prefrontal cortical inputs to the rat amygdala: spatial relationships to presumed dopamine axons and D1 and D2 receptors. Brain Struct. Funct. 213, 159-175. doi: 10.1007/ s00429-008-0180-6

Prager, E. M., Bergstrom, H. C., Wynn, G. H., and Braga, M. F. (2016). The basolateral amygdala $\gamma$-aminobutyric acidergic system in health and disease. J. Neurosci. Res. 94, 548-567. doi: 10.1002/jnr.23690

Rostkowski, A. B., Leitermann, R. J., and Urban, J. H. (2013). Differential activation of neuronal cell types in the basolateral amygdala by corticotropin releasing factor. Neuropeptides 47, 273-280. doi: 10.1016/j.npep.2012. 12.004
Równiak, M., Kolenkiewicz, M., and Kozłowska, A. (2017). Parvalbumin, but not calretinin, neurons express high levels of $\alpha 1$-containing GABAA receptors, $\alpha 7$ containing nicotinic acetylcholine receptors and D2-dopamine receptors in the basolateral amygdala of the rat. J. Chem. Neuroanat. 86, 41-51.

Rutherford, K. M., Piastowska-Ciesielska, A., Donald, R. D., Robson, S. K., Ison, S. H., Jarvis, S., et al. (2014). Prenatal stress produces anxiety prone female offspring and impaired maternal behaviour in the domestic pig. Physiol. Behav. 129, 255-264. doi: 10.1016/j.physbeh.2014.02.052

Sachser, N., Hennessy, M. B., and Kaiser, S. (2011). Adaptive modulation of behavioural profiles by social stress during early phases of life and adolescence. Neurosci. Biobehav. Rev. 35, 1518-1533. doi: 10.1016/j.neubiorev.2010.09.002

Sah, P., Faber, E. S., De Armentia, M. L., and Power, J. (2003). The amygdaloid complex: anatomy and physiology. Physiol. Rev. 83, 803-834. doi: 10.1152/ physrev.00002.2003

Sanders, S. K., and Shekhar, A. (1995). Regulation of anxiety by GABAA receptors in the rat amygdala. Pharmacol. Biochem. Behav. 52, 701-706.

Sandi, C., and Richter-Levin, G. (2009). From high anxiety trait to depression: a neurocognitive hypothesis. Trends Neurosci. 32, 312-320. doi: 10.1016/j.tins. 2009.02.004

Saveanu, R. V., and Nemeroff, C. B. (2012). Etiology of depression: genetic and environmental factors. Psychiatr. Clin. North Am. 35, 51-71. doi: 10.1016/j.psc. 2011.12.001

Schlotz, W., Yim, I. S., Zoccola, P. M., Jansen, L., and Schulz, P. (2011). The Perceived stress reactivity scale: measurement invariance, stability, and validity in three countries. Psychol. Assess. 23, 80-94. doi: 10.1037/a0021148

Schneiderman, N., Ironson, G., and Siegel, S. D. (2005). Stress and health: psychological, behavioral, and biological determinants. Annu. Rev. Clin. Psychol. 1, 607-628. doi: 10.1146/annurev.clinpsy.1.102803.144141

Sickmann, H. M., Arentzen, T. S., Dyrby, T. B., Plath, N., and Kristensen, M. P. (2015). Prenatal stress produces sex-specific changes in depression-like behavior in rats: implications for increased vulnerability in females. J. Dev. Orig. Health Dis. 6, 462-474. doi: 10.1017/S2040174415001282

Sieghart, W. (2006). Structure, pharmacology, and function of GABAA receptor subtypes. Adv. Pharmacol. 54, 231-263.

Sieghart, W., and Sperk, G. (2002). Subunit composition, distribution and function of GABA(A) receptor subtypes. Curr. Top. Med. Chem. 2, 795-816.

Sigel, E., and Lüscher, B. P. (2011). A closer look at the high affinity benzodiazepine binding site on GABAA receptors. Curr. Top. Med. Chem. 11, 241-246.

Skórzewska, A., Lehner, M., Wisłowska-Stanek, A., Turzyńska, D., Sobolewska, A., Krząścik, P., et al. (2015). GABAergic control of the activity of the central nucleus of the amygdala in low- and high-anxiety rats. Neuropharmacology 99 , 566-576. doi: 10.1016/j.neuropharm.2015.08.039

Smith, A. S., Lieberwirth, C., and Wang, Z. (2013). Behavioral and physiological responses of female prairie voles (Microtus ochrogaster) to various stressful conditions. Stress 16, 531-539. doi: 10.3109/10253890.2013.794449

Spampanato, J., Polepalli, J., and Sah, P. (2011). Interneurons in the basolateral amygdala. Neuropharmacology 60, 765-773. doi: 10.1016/j.neuropharm.2010. 11.006

Sparta, D. R., Jennings, J. H., Ung, R. L., and Stuber, G. D. (2013). Optogenetic strategies to investigate neural circuitry engaged by stress. Behav. Brain Res. 255, 19-25. doi: 10.1016/j.bbr.2013.05.007

Stefanits, H., Milenkovic, I., Mahr, N., Pataraia, E., Hainfellner, J. A., Kovacs, G. G., et al. (2018). GABAA receptor subunits in the human amygdala and hippocampus: immunohistochemical distribution of 7 subunits. J. Comp. Neurol. 526, 324-348. doi: 10.1002/cne.24337

Stephens, M. A., and Wand, G. (2012). Stress and the HPA axis: role of glucocorticoids in alcohol dependence. Alcohol. Res. 34, 468-483.

Steptoe, A., and Kivimäki, M. (2012). Stress and cardiovascular disease. Nat. Rev. Cardiol. 9, 360-370. doi: 10.1038/nrcardio.2012.45

Suarez-Roca, H., Leal, L., Silva, J. A., Pinerua-Shuhaibar, L., and Quintero, L. (2008). Reduced GABA neurotransmission underlies hyperalgesia induced by repeated forced swimming stress. Behav. Brain Res. 189, 159-169. doi: 10.1016/ j.bbr.2007.12.022

Tian, Z., Wang, Y., Zhang, N., Guo, Y. Y., Feng, B., Liu, S. B., et al. (2013). Estrogen receptor GPR30 exerts anxiolytic effects by maintaining the balance between GABAergic and glutamatergic transmission in the basolateral amygdala of ovariectomized mice after stress. Psychoneuroendocrinology 38, 2218-2233. doi: 10.1016/j.psyneuen.2013.04.011 
Tsoory, M., Cohen, H., and Richter-Levin, G. (2007). Juvenile stress induces a predisposition to either anxiety or depressive-like symptoms following stress in adulthood. Eur. Neuropsychopharmacol. 17, 245-256. doi: 10.1016/j.euroneuro. 2006.06.007

Tzanoulinou, S., García-Mompó, C., Castillo-Gómez, E., Veenit, V., Nacher, J., and Sandi, C. (2014). Long-term behavioral programming induced by peripuberty stress in rats is accompanied by GABAergic-related alterations in the Amygdala. PLoS One 9:e94666. doi: 10.1371/journal.pone.0094666

Ulrich-Lai, Y. M., Fulton, S., Wilson, M., Petrovich, G., and Rinaman, L. (2015). Stress exposure, food intake and emotional state. Stress 18, 381-399. doi: 10. 3109/10253890.2015.1062981

Varodayan, F. P., Bajo, M., Soni, N., Luu, G., Madamba, S. G., Schweitzer, P., et al. (2017). Chronic alcohol exposure disrupts CB1 regulation of GABAergic transmission in the rat basolateral amygdala. Addict. Biol. 22, 766-778. doi: 10.1111/adb.12369

Wang, G. Y., Zhu, Z. M., Cui, S., and Wang, J. H. (2016). Glucocorticoid induces incoordination between glutamatergic and GABAergic neurons in the amygdala. PLoS One 11:e0166535. doi: 10.1371/journal.pone. 0166535

Wisłowska-Stanek, A., Lehner, M., Skórzewska, A., Krząścik, P., Maciejak, P., Szyndler, J., et al. (2013). Changes in the brain expression of alpha-2 subunits of the GABA-A receptor after chronic restraint stress in low- and high-anxiety rats. Behav. Brain Res. 253, 337-345. doi: 10.1016/j.bbr.2013.07.042

Xu, C., Zhang, W., Rondard, P., Pin, J. P., and Liu, J. (2014). Complex GABAB receptor complexes: how to generate multiple functionally distinct units from a single receptor. Front. Pharmacol. 5:12. doi: 10.3389/fphar.2014.00012
Yang, L., Omori, K., Omori, K., Otani, H., Suzukawa, J., and Inagaki, C. (2003). GABAC receptor agonist suppressed ammonia-induced apoptosis in cultured rat hippocampal neurons by restoring phosphorylated BAD level. J. Neurochem. 87, 791-800.

Yu, K., Ahrens, S., Zhang, X., Schiff, H., Ramakrishnan, C., Fenno, L., et al. (2017). The central amygdala controls learning in the lateral amygdala. Nat. Neurosci. 20, 1680-1685. doi: 10.1038/s41593-017-0009-9

Zuloaga, D. G., Carbone, D. L., and Handa, R. J. (2012). Prenatal dexamethasone selectively decreases calretinin expression in the adult female lateral amygdala. Neurosci. Lett. 521, 109-114. doi: 10.1016/j.neulet.2012.05.058

Zuloaga, D. G., Carbone, D. L., Hiroi, R., Chong, D. L., and Handa, R. J. (2011). Dexamethasone induces apoptosis in the developing rat amygdala in an age, region-, and sex-specific manner. Neuroscience 199, 535-547. doi: 10.1016/j. neuroscience.2011.09.052

Conflict of Interest Statement: The authors declare that the research was conducted in the absence of any commercial or financial relationships that could be construed as a potential conflict of interest.

Copyright (C) 2018 Jie, Yin, Yang, Yang, Gao, Lv and Li. This is an open-access article distributed under the terms of the Creative Commons Attribution License (CC BY). The use, distribution or reproduction in other forums is permitted, provided the original author(s) and the copyright owner(s) are credited and that the original publication in this journal is cited, in accordance with accepted academic practice. No use, distribution or reproduction is permitted which does not comply with these terms. 